\title{
Institutional Control Policies and Implementation for the Area 5 and Area 3 Radioactive Waste Management Sites
}

\author{
Prepared for \\ U.S. Department of Energy \\ National Nuclear Security Administration \\ Nevada Site Office

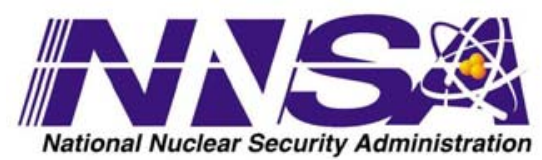 \\ Prepared by \\ Bruce Crowe \\ Stoller-Navarro Joint Venturel \\ Battelle Memorial Institute
}

Vefa Yucel, Greg Shott, and Denise Wieland National Security Technologies, LLC

November 2007 


\title{
DISCLAIMER
}

Reference herein to any specific commercial product, process, or service by trade name, trademark, manufacturer, or otherwise, does not necessarily constitute or imply its endorsement, recommendation, or favoring by the U.S. Government or any agency thereof.

Available for sale to the public, in paper, from -

\author{
U.S. Department of Commerce \\ National Technical Information Service \\ 5285 Port Royal Road \\ Springfield, VA 22161-0002 \\ Phone: (800) 553-6847 \\ Fax: (703) 605-6900 \\ E-mail: orders@ntis.gov \\ Online Ordering: http://www.ntis.gov/ordering.htm
}

Available electronically at http://www.osti.gov/bridge

Available for a processing fee to U.S. Department of Energy and its contractors, in paper, from -

\author{
U.S. Department of Energy \\ Office of Scientific and Technical Information \\ P.O. Box 62 \\ Oak Ridge, TN 37831-0062 \\ Phone: (865) 576-8401 \\ Fax: (865) 576-5728 \\ E-mail: reports@adonis.osti.gov
}




\title{
Institutional Control Policies and Implementation for the Area 5 and Area 3 Radioactive Waste Management Sites
}

\author{
Prepared for \\ U.S. Department of Energy \\ National Nuclear Security Administration \\ Nevada Site Office

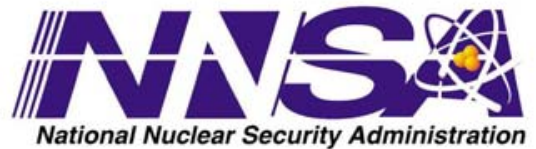 \\ Prepared by \\ Bruce Crowe \\ Stoller-Navarro Joint Venturel \\ Battelle Memorial Institute
}

Vefa Yucel, Greg Shott, and Denise Wieland National Security Technologies, LLC

November 2007 
This Page Intentionally Left Blank 


\section{CONTENTS}

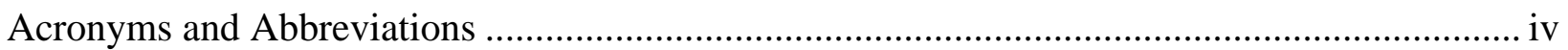

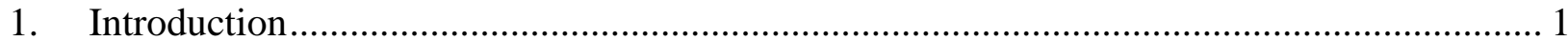

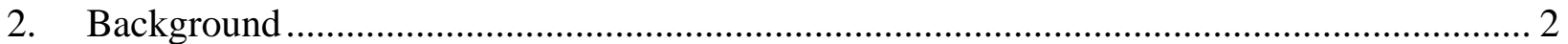

3. A Unified Approach to Institutional Control Policy ........................................................ 3

4. The Corrective Action Strategy for the UGTA CAUs.................................................. 4

5. Implementation of the Institutional-Control Policy .................................................... 5

6. Policy Implications for Compliance Determination under DOE Order 435.1...................... 7

7. Policy Implications for Compliance Determination under Title 40 CFR 191 ..................... 9

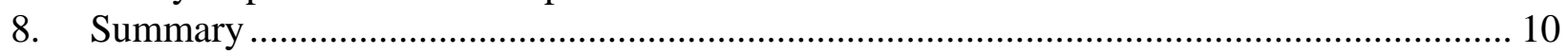

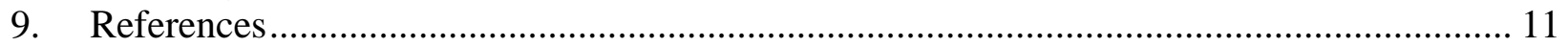

\section{LIST OF TABLES}

Table 1. Exposure Pathways for MOP Exposure Scenarios .................................................. 8

Table 2. Exposure Pathways for Acute IHI Scenarios........................................................... 9 


\section{ACRONYMS AND ABBREVIATIONS}

$\mathrm{BN}$

CA composite analysis

CAU Corrective Action Unit

CFR Code of Federal Regulations

DAS Disposal Authorization Statement

DOE U.S. Department of Energy

EM Environmental Management

FFACO Federal Facility Agreement and Consent Order

FY fiscal year

GCD greater confinement disposal

IHI inadvertent human intrusion

LFRG Low-Level Radioactive Waste Review Group

LLW low-level waste

m meter(s)

MOP member of the public

$\mathrm{mSv} \quad$ milliSievert

NDEP Nevada Division of Environmental Protection

Neptune Neptune and Company, Inc.

NNSA/NSO U.S. Department of Energy, National Nuclear Security Administration Nevada Site Office

NTS Nevada Test Site

PA performance assessment

RWMS Radioactive Waste Management Site

SDWA Safe Drinking Water Act

TEDE Total Effective Dose Equivalent

TRU transuranic

UGTA Underground Test Area 


\section{Introduction}

The U.S. Department of Energy (DOE), National Nuclear Security Administration Nevada Site Office (NNSA/NSO) has implemented varying institutional control policies in performance assessment/composite analysis (PA/CA) calculations for the Area 5 and Area 3 Radioactive Waste Management Sites (RWMSs) (Shott et al., 1998; 2000; Bechtel Nevada [BN] and Neptune and Company Inc. [Neptune], 2006). The facilities are within the actively maintained boundaries of the Nevada Test Site (NTS) that are enforced by NNSA/NSO. Under current policies, access required for exposure of the member of public (MOP) or the inadvertent human intruder (IHI) is prohibited. Uncertainties affecting institutional control policies are the duration and effectiveness of the controls during the post-closure period. Implementing a uniform set of institutional control policies for the RWMSs that encompasses waste management and environmental restoration programs and is consistent with the end-state vision for the environmental management programs for the NTS (DOE, 2006) is a primary goal of the maintenance program.

The NNSA/NSO Performance Management Plan (DOE, 2002) complies with DOE Policy P455.1, "Use of Risk-Based End States” (DOE, 2003a). Expected future land uses are a driver in selecting acceptable end state conditions and clean-up goals for the NTS. NNSA/NSO Environmental Management's (EM's) land management assumptions and framework for Environmental Management activities are as follows:

The NTS will remain under federal control in perpetuity as an NNSA test site, and the large buffer zone surrounding the NTS (the Nevada Test and Training Range) is assumed to remain under the control of the U.S. Air Force. There are no plans for transfer of any NTS lands to other agencies or public entities. Access will continue to be restricted to the NTS and the surrounding areas.

For management purposes, NNSA/NV EM activities have been established based on the source of contamination and type of waste requiring management. Environmental Restoration activities within the State of Nevada fall under the purview of a formal regulatory agreement, the Federal Facility Agreement and Consent Order (FFACO); Environmental Restoration activities outside the State of Nevada fall under the purview of each affected State's regulatory framework but are planned and negotiated with the State using the FFACO Corrective Action Strategy framework for applicable activities. Waste Management activities are governed by the Federal Facility Compliance Act and Consent Order (and the Mutual Consent Agreement (MCA). A Joint Low-Level Waste Oversight Agreement is in place to allow state of Nevada representatives to participate in review and approval processes associated with waste receipt and disposal operations (DOE, 2002). 
The purpose of this document is to describe institutional control policies implemented in the past PA/CA documentation, to discuss concerns noted in reviews of PA/CA documents, and to describe a new basis for institutional control at NTS disposal facilities. The new basis uses combined controls based on policies identified in the end-state vision (DOE, 2006); policies established through the FFACO, (1996) for Hazard Area 1, the Underground Test Area (UGTA) Project, and newly established NNSA policies for the Nevada Site Office.

\section{Background}

The Area 5 RWMS PA assumed loss of institutional control after 100 years followed by postdrilling and intruder agriculture scenarios for the IHI. Human intrusion was assumed to occur (probability $=1$ ). The Area 3 RWMS PA/CA used a probability distribution for the onset of loss of institutional control based on the results of an expert judgment elicitation of the probability of IHI. Human intrusion was assumed to occur (probability $=1$ ) after loss of institutional control (Black et al., 2001). The current version of the Area 5 RWMS PA uses a probability distribution for the onset of loss of institutional control, and weights the chronic doses by the probability of IHI for the area (footprint) of specific waste disposal units (shallow land burial, Greater Confinement Disposal, Pit 6).

Institutional control policies have been identified in conditional acceptance requirements for the Disposal Authorization Statements (DASs) issued by the DOE based on recommendations from formal reviews by the Low-Level Radioactive Waste Review Group (LFRG). Specific conditions involving institutional control include the following:

1. The site is to better justify the selection of 100 years until an intruder would access the site (memorandum, Cowan to Dever, 1996).

2. Lack of justification for excluding particular intruder exposure scenarios based on exhumed waste and lack of sensitivity analysis regarding the assumed 250 years of institutional controls (memorandum, Fiore and Frei to Carlson, 1999).

3. The DAS for the Area 5 RWMS PA and CA identified two areas where the initial site design did not meet the performance objectives. Two conditions were imposed, both related to the IHI scenarios:

a. As a result of the post-drilling intruder scenario as stated in Section 5.1 of the 1998 PA, the specific radionuclide concentration or inventory limits shall be imposed on Pit 6 to ensure that performance will not be exceeded, and

b. The closure plan shall require a closure cap thickness of at least 4 meters as stated in Section 5.1 of the 1998 PA to ensure that performance objectives for the agriculture scenario will not be exceeded.

4. The subsequent DAS for the Area 3 RWMS PA and CA identified the following in a December 2000 memorandum (Fiore to Carlson, 2000): 
“.. . a qualitative assessment including an options analysis of the effect of groundwater contamination resulting from underground testing. The qualitative assessment is expected to show that the potential dose would effectively be mitigated by the control of land in the vicinity of the Area 3 Radioactive Waste Management Site. Before any portion of the Nevada Test Site is considered for a reduction in institutional controls, Nevada Operations Office (now NSO) will have quantified the potential dose from underground testing residues and taken measures to mitigate the dose, as appropriate (memorandum, Fiore to Carlson, 2001).

5. In the response to the remaining unclosed conditions from the 2001 DAS, the LFRG conditionally accepted the option for the UGTA source of "Identification of contaminant boundaries and exclusion of public access" (memorandum, Frei to Carlson, 2002).

6. Addendum 2 to the Performance Assessment for the Area 5 Radioactive Waste Management Site at the Nevada Test Site, Nye County, Nevada (BN and Neptune, 2006) includes intruder impacts under the assumption that land-use policies become ineffective. The probability of intrusion scenarios for the Area 5 RWMS is based on the results of an expert judgment elicitation of Subject Matter Experts (BN, 2002; Black et al., 2001). The intruder results are reported in the PA addendum as the product of intrusion probability and the intruder scenario total effective dose equivalents (TEDEs) (probability weighted doses).

\section{A Unified Approach to Institutional Control Policy}

The NNSA/NSO, in response to concerns over consistency issues in numerical modeling and land-use policies, has conducted an evaluation of program assumptions across the waste management and environmental restoration programs. A key issue is consistency in land-use policies and treatment of scenarios for IHI at the NTS.

Three significant land-use policies have been identified. First, the NTS is an NNSA/NSOcontrolled site and the policy intent of NNSA/NSO is to retain control of the NTS "in perpetuity." The NNSA/NSO has identified the Area 5 and Area 3 RWMSs as Restricted Use Zones under control of the NNSA/NSO Manager in local directives (NNSA/NSO, 2006) and are sites with ". . . a compelling need (such as security, restricted access, remote location, physical characteristic) to be within the secure boundaries of the NTS.” Second, assessment of radioactive contamination of groundwater from underground testing of nuclear weapons is the highest priority EM program for the NTS. Underground testing resulted in over 132 million curies of radioactivity in the subsurface of the NTS. The UGTA Project activities addressing deep underground radioactive activities are the highest priority with the state of Nevada regulators due to the limited availability of water resources (DOE, 2006). Third, the Area 3 RWMS is within the Yucca Flat Corrective Action Unit ([CAU], where a CAU is a grouping of corrective action sites) and the Area 5 RWMS is in Frenchman Flat, less than 2 miles from one of the Corrective Action Sites of the Frenchman Flat CAU. The NNSA/NSO Assistant Manager of EM has administratively agreed to include the Area 5 RWMS area within the anticipated groundwater use restriction area. The UGTA CAUs are identified as Restricted Use Zones in local directives (NNSA/NSO, 2006). The corrective action strategy for the UGTA CAUs is 
identified in Appendix VI of the FFACO. The following sections provide a brief overview of the UGTA program strategy.

\section{The Corrective Action Strategy for the UGTA CAUs}

The corrective action strategy for UGTA is based on a corrective action process where boundaries are identified for each CAU that encompasses geographic areas containing groundwater that may be unsafe for domestic and municipal use. Each UGTA CAU will be evaluated through data collection, evaluation, and numerical modeling leading to predictions of the maximum extent of groundwater flow and contaminant transport from underground testing of nuclear weapons. The vertical and horizontal extent of contaminant migration will be predicted for each CAU. The primary objective of the modeling is to predict the contaminant boundary and the uncertainty associated with the predictions where contamination exceeds the Safe Drinking Water Act (SDWA) standards. The numerical model requirements are to predict the location of individual contaminant boundaries within 1,000 years using the 95th percentile of a probability density function to define the uncertainty in the location of the contaminant boundary. The NNSA/NSO and the Nevada Department of Environmental Protection (NDEP) will negotiate a compliance boundary based on the contaminant boundary. A current assumption of UGTA is that contaminant control and/or remediation is not technologically or economically feasible (DOE, 2006). With the establishment of a regulatory compliance boundary, remedial actions will be evaluated and a five-year monitoring plan will be developed to assess the adequacy of CAU surveillance. If the monitoring plan is found acceptable, a closure plan will be developed, followed by a long-term closure monitoring program.

The expectation of the UGTA is that protection of human health and the environment will be based on controlled access to areas of contamination (areas within the compliance boundary). The use of restrictions for controlling land access is defined in Section 6.0 of the FFACO Handbook, and the corrective action strategy for the UGTA is described in Appendix VI (DOE, 2004). A use-restriction form and map is developed by the NNSA/NSO contractor as part of the draft closure report. Pending approval by the NDEP, the form and map of the use restriction become the official records for documenting sites with remaining contamination after closure. The NNSA/NSO, the Bureau of Land Management, and the U.S. Air Force will maintain userestriction records as long as the land is under their jurisdiction.

The regional groundwater flow models for the Death Valley Regional Groundwater Flow System have been developed and used to provide boundary conditions and boundary fluxes for UGTA CAUs (DOE, 1997; D’Agnese et al., 1997; Belcher, 2004). The Frenchman Flat CAU has progressed through the first phase of the data collection, evaluation, and modeling cycle (flow and transport models). An external peer review of the modeling results found the work to be insufficient to resolve the CAU goals, primarily from an incomplete assessment of all components of uncertainty (particularly conceptual model uncertainty) (IT Corporation, 1999).

An amended corrective action investigation plan was developed and approved by the NDEP for the second phase of data gathering and modeling. New exploratory drilling, supplemented by geophysical and water geochemistry studies, were completed. This work provided the basis for establishing multiple alterative conceptual models of the hydrostratigraphic framework of the 
Frenchman Flat CAU (BN, 2005). The alternative hydrostratigraphic frameworks were included with varying boundary conditions, boundary fluxes, and alternative recharge models, to develop revised flow models. The flow modeling phase has been completed, and a final report developed (Stoller-Navarro, 2006) that is being reviewed by the NDEP.

Transport modeling, incorporating conceptual model uncertainty from the flow modeling and parameter uncertainty, is underway. Current results are inconclusive as to whether the Area 5 facility will be included in the contaminant and compliance boundaries associated with a cluster of underground tests in northern Frenchman Flat because of combined uncertainty in groundwater flow directions, flat groundwater gradients, and limited transport in 1,000 years. The model boundaries are expected to be close to the Area 5 RWMS and the Assistant Manager for EM at the NNSA/NSO has administratively agreed that the facility will be included within the contaminant and compliance boundaries for the Frenchman Flat CAU.

The alternative hydrostratigraphic framework models have been completed for the Yucca Flat CAU (BN, 2006). Work on the development of the Yucca Flat CAU model is ongoing. The Area 3 facility uses subsidence craters developed from underground testing of nuclear weapons and is within the expected contaminant and compliance boundaries for the Yucca Flat CAU.

\section{Implementation of the Institutional-Control Policy}

The development of a consistent and fully defensible institutional-control policy remains problematic for DOE and NNSA. Regnier and Wallo (2006) discuss multiple aspects of regulatory policies for the DOE with a focus on time of regulatory compliance and institutional control policies. They argue that a 1,000-year compliance interval provides a realistic upper limit for regulations that balance the uncertainty of PAs and the risk, cost, and benefits of protection of human health and safety from a multi-generational perspective.

Regnier and Wallo (2006) also note the difficulty of establishing a scientific basis for prediction of human intrusion and the limiting nature of IHI calculations on management of facilities for shallow-land disposal of low-level radioactive waste. The National Academy of Sciences has argued repeatedly in program assessments sponsored by the DOE that it is not feasible to make meaningful predictions about the probability of IHI or to incorporate alternative scenarios of human intrusion into risk-based assessments (National Academy of Sciences, 1995; 1999). The DOE policies endorse the use of institutional controls to prevent or limit inadvertent human exposure scenarios (DOE, 2003b) and implementation of risk-based end states. The current long-term end state vision for the NTS is:

... to restore the environment to an extent that will allow the maximum continuation of the national security mission conducted by the NNSA/NSO, the national laboratories, and the contractors. This vision includes the removal of only the contamination that poses an unacceptable risk to workers conducting planned site operations in support of the NNSA/NSO mission and characterizing/ stabilizing the rest of the contamination to ensure that remaining levels do not spread to the surrounding environment and pose an unacceptable risk (DOE, 2006). 
The primary goal for the NTS end-state vision includes the completion of the described UGTA modeling predictions with quantification of uncertainty for the contaminant boundary and negotiation of a compliance boundary and closure document after completion of site monitoring.

The following changes will be implemented in the NNSA/NSO policies for institutional control of the Area 5 and Area 3 RWMSs for consistency with the NTS end-state vision:

1. The timing of the onset of the loss of institutional control will continue to be assessed as a probability distribution that is based on and justified by local conditions.

2. The probability of IHI will no longer be applied in risk-modified dose calculations consistent with the guidance of the National Academy of Sciences.

3. The Area 5 and Area 3 facilities will assume land-use restrictions consistent with NNSA directives and the UGTA/FFACO policies for the NTS.

4. The land-use restrictions will prohibit public access to contaminated groundwater within the NDEP compliance-negotiated boundaries for 1,000 years. A 1,000-year duration for land-use restrictions is not specified in the FFACO (DOE, 1996), but is a recognized requirement of the definition of the contaminant boundary (page VI-3-3), the performance criteria (page VI-3-4), and the requirements for implementing the SDWA (page VI-3-12). (All page references are from Appendix VI of the FFACO [DOE 1996].)

5. The PA and CA for the Area 5 and Area 3 facilities demonstrate that there is insufficient transport to establish a downward pathway beneath the facilities to groundwater for contaminants during the 1,000-year compliance period (Shott et al., 1998; 2000;

$\mathrm{BN}, 2006)$. The only release pathways that allow interaction between the disposal facility inventory and the UGTA groundwater contamination is from drilling to groundwater near the waste disposal facilities (combined atmospheric and groundwater pathways). The landuse restrictions eliminate groundwater drilling as a release pathway and eliminate the agriculture resident and the water-drilling IHI scenarios from consideration in the PA and CA for the Area 5 and Area 3 RWMSs.

6. The land-use restrictions are assumed to eliminate long-term access to groundwater for the chronic post-drilling and intruder agriculture scenarios. The policies are not expected to be $100 \%$ effective for shorter time spans (months) and will not prevent the acute groundwater drilling and construction scenarios.

The PA/CA maintenance program issues that arise from the consideration of land-use restrictions are discussed below, first considering the DOE Order 435.1, "Radioactive Waste Management" performance objectives pertaining to the low-level waste (LLW) disposals; and second, the Title 40 Code of Federal Regulations (CFR) 191, “Environmental Radiation Protection Standards for Management and Disposal of Spend Nuclear Fuel, High-Level, and Transuranic Radioactive Wastes,” performance objectives pertaining to the transuranic (TRU) waste in four greater confinement disposal (GCD) boreholes and a trench (T04C). 


\section{Policy Implications for Compliance Determination under DOE Order $\mathbf{4 3 5 . 1}$}

Protection of groundwater resources and inadvertent intruders are requirements under DOE Order 435.1, as specified in DOE Manual 435.1-1, “Radioactive Waste Management Manual”. The compliance determination for the LLW facilities at the DOE complex is based on the following performance objectives:

1. The dose to representative MOPs shall not exceed 0.25 milliSieverts (mSv) in a year total TEDE from all exposure pathways, excluding the dose from radon and its progeny in air.

2. The dose to representative MOPs via the air pathway shall not exceed $0.10 \mathrm{mSv}$ in a year TEDE, excluding the dose from radon and its progeny.

3. The release of radon shall be less than an average flux of 0.74 Becquerel per square meter per second at the surface of the disposal facility. Alternatively, a limit of 0.0185 Becquerel per liter of air may be applied at the boundary of the facility.

Only the compliance determinations for the performance objectives ( 1 and 2 above) are impacted by the land-use and institutional-control policy. Representative members of the public are interpreted to be members of a critical group engaged in typical activities expected for the region. The critical group includes those MOPs exposed to the highest radionuclide releases from the site. These considerations (including when and where MOPs can be exposed to releases from the facilities) have led to defining MOP scenarios for the PA/CA evaluations. The original Area 5 RWMS PA (Shott et al., 1998), and the current addendum (BN and Neptune, 2006) evaluated three MOP scenarios:

- Transient occupancy

- Open rangeland

- Resident farmer scenario

In the transient occupancy scenario, individuals were assumed to use the site on a short-term basis for recreational activities. The open rangeland scenario envisioned a ranch with individuals living at off-site locations with available water (Cane Spring and Indian Springs), but having cattle grazing on site. The resident farmer scenario, similar to the transient scenario, is assumed to be located at 100 meters (m) (330 feet [ft]) from the RWMS boundary with water supplied from a groundwater well. This scenario location is assumed to be similar to the expected boundary of land-use restrictions under the UGTA FFACO agreements. The primary distinction between the open rangeland scenario conducted for receptors at Cane Spring and the NTS Boundary, and the resident farmer is in the location of the assumed residence. The soil sourceterm for the open rangeland scenarios, with the exception of the beef and milk pathways wherein cattle and cows are assumed to graze at the RWMS, is generated by modeling atmospheric transport and deposition of RWMS soils at these remote locations. A summary of the exposure routes evaluated in each of these scenarios is provided in Table 1. 
In the Area 5 RWMS CA, the MOP dose was computed using the resident scenario with agriculture (BN, 2001), located $100 \mathrm{~m}(330 \mathrm{ft})$ from the edge of the RWMS boundary. Two MOP scenarios were implemented in the Area 3 RWMS PA/CA (Shott et al., 2000): the resident and the resident with agriculture (in both scenarios, the MOP being located at $100 \mathrm{~m}$ [330 ft] from the RWMS boundary). The compliance determination was based on the resident scenario without agriculture.

To bring consistency to the evaluation of the MOP dose for the Area 5 and Area 3 RWMSs, and to be consistent with NNSA/NSO's land-use and institutional control policies, the maintenance program is adopting the resident without agriculture as the compliance scenario in future PA/CA modeling. DOE M 435.1-1 requires that doses be calculated for the critical group assuming average living habits. Cultivation of food is rare for residents of southern Nevada living at locations without shallow groundwater and is not considered an average habit for PA/CA modeling.

Table 1. Exposure Pathways for MOP Exposure Scenarios

\begin{tabular}{|l|c|c|c|c|}
\hline \multicolumn{1}{|c|}{ Exposure Pathway } & $\begin{array}{c}\text { Transient } \\
\text { Occupancy }\end{array}$ & $\begin{array}{c}\text { Open } \\
\text { Rangeland }\end{array}$ & $\begin{array}{c}\text { Resident } \\
\text { Farmer }\end{array}$ & Resident \\
\hline $\begin{array}{l}\text { Inhalation of resuspended soil } \\
\text { particulates }\end{array}$ & $X$ & $X$ & $X$ & $X$ \\
\hline $\begin{array}{l}\text { Inhalation of gaseous } \\
\text { radionuclides (tritiated water } \\
\text { vapor, carbon dioxide, noble } \\
\text { gases excepting radon) }\end{array}$ & $X$ & $X$ & $X$ & $X$ \\
\hline External irradiation from soil & $X$ & $X^{\dagger}$ & $X^{\dagger}$ & $X^{\dagger}$ \\
\hline $\begin{array}{l}\text { External irradiation from } \\
\text { radionuclides in air } \\
\text { (immersion) }\end{array}$ & $X$ & $X$ & $X$ & $X$ \\
\hline Inadvertent soil ingestion & $X$ & $X$ & $X$ & $X$ \\
\hline Ingestion of garden produce & & $X$ & $X$ & \\
\hline $\begin{array}{l}\text { Ingestion of beef from range- } \\
\text { fed cattle }\end{array}$ & & $X$ & $X$ & \\
\hline $\begin{array}{l}\text { Ingestion of meat and eggs } \\
\text { from range-fed poultry }\end{array}$ & & $X$ & $X$ & \\
\hline $\begin{array}{l}\text { Ingestion of milk from range- } \\
\text { fed cows }\end{array}$ & & & $X$ & \\
\hline
\end{tabular}

${ }^{\dagger}$ - Does not include dose from short-lived ${ }^{222} \mathrm{Rn}$ progeny because receptor is off site.

The MOP for the Area 5 RWMS PA/CA will remain $100 \mathrm{~m}$ (330 ft) away from the RWMS boundary. The MOP for the Area 3 RWMS PA/CA would be located several hundred meters away from the RWMS boundary, anticipating that the UGTA containment boundary for the Yucca Flat CAU will be far away from the UGTA sources beneath the Area 3 RMWS. Because the containment boundary for Area 3 RWMS will not be available before fiscal year (FY) 2021 (National Security Technologies, LLC, 2007), the current 100-m (330-ft) boundary is retained for the MOP dose calculations for the Area 3 RWMS PA and CA. 
The consequence of NNSA/NSO's land-use policy and the institutional-control policy combined may preclude a community scenario within the 1,000-year compliance period for compliance determination for either the Area 3 or Area 5 RWMS. A future NTS landlord decision regarding the release of the NTS lands for public access is uncertain. Therefore, the PA/CA maintenance program will continue to use the probability distributions established in the current versions of the GoldSim ${ }^{\circledR} \mathrm{PA} / \mathrm{CA}$ models to initiate the time after closure when the MOP scenario can occur. This approach assumes both active and passive institutional controls for the Area 5 and Area 3 facilities and is consistent with the IHI policies for the tank farms at the Hanford site (Hewitt et al., 2006).

Institutional control is not assumed to preclude short-term intrusion into the site. Therefore, the PA will evaluate an acute drilling and construction IHI scenario. The acute drilling scenario estimates the dose to a drill crew drilling a water well through a disposal cell. The acute construction scenario estimates the dose to a construction crew excavating a septic tank or basement during construction of a residence. Exposure pathways for both scenarios are summarized in Table 2.

Table 2. Exposure Pathways for Acute IHI Scenarios

\begin{tabular}{|l|c|c|}
\hline \multicolumn{1}{|c|}{ Exposure Pathway } & Drilling & Construction \\
\hline Inhalation of resuspended soil particulates & $\mathrm{X}$ & $\mathrm{X}$ \\
\hline $\begin{array}{l}\text { Inhalation of gaseous radionuclides (tritiated water vapor, carbon } \\
\text { dioxide, noble gases excepting radon) }\end{array}$ & $\mathrm{X}$ & $\mathrm{X}$ \\
& & $\mathrm{X}$ \\
\hline External irradiation from soil & $\mathrm{X}$ & $\mathrm{X}$ \\
\hline External irradiation from radionuclides in air (immersion) & $\mathrm{X}$ & $\mathrm{X}$ \\
\hline Inadvertent soil ingestion & \\
\hline
\end{tabular}

\section{Policy Implications for Compliance Determination under Title 40 CFR 191}

A PA for the TRU materials emplaced in four GCD boreholes at the Area 5 RWMS was prepared by Sandia National Laboratories (Cochran et al., 2001) to demonstrate consistency with the requirements of Title 40 CFR 191. A special analysis PA is also being performed for the TRU materials in trench T04C. Title 40 CFR 191 has the following requirements:

- $\quad$ Containment Requirements of Title 40 CFR 191.13

- $\quad$ Assurance Requirements of Title 40 CFR 191.14

- Individual Protection Requirements of Title CFR 191.15

- Groundwater Protection Requirements of Title 40 CFR 191.16, “Alternative Provisions for Disposal”

As requested by the NNSA/NSO, the GCD PA was reviewed by the Transuranic Waste Disposal Facility Federal Review Group in FY 2001. The review was found acceptable, with the condition that the NNSA/NSO will address the assurance requirement deficiencies and ensure 
compliance with the 1993 version of Title 40 CFR 191 as part of the closure of the Area 5 RWMS (Frei, MW, 2002).

Title 40 CFR 191 requires that the TRU performance evaluation limit the institutional control period to a maximum of 100 years, and consider both the disturbed (human intrusion events as well as natural events such as climate change) and the undisturbed performance of a TRU waste facility for a 10,000-year compliance period.

Performed with these assumptions, the GCD PA provides a very conservative evaluation of the performance of the TRU materials in the GCD boreholes. The cumulative releases of TRU radionuclides from the GCD facility over a 10,000-year period (Containment Requirements) were shown to be well below the allowable releases under the regulation. Drill cuttings from well-drilling intrusion events into the waste were included in the release calculations. The dose to MOP (Individual Protection Requirements) was also shown to be well below the dose limit. Both an off-site resident-farmer and on-site homebuilder MOP scenario were evaluated for a 1,000-year compliance period. The homebuilder was assumed to reside on top of the GCD borehole, and all releases from the boreholes were cumulated into the soil in a garden. Well-drilling intrusion was assumed to occur in 2170 (100 years after the facility closure).

\section{Summary}

The NNSA/NSO will use the following institutional control policies in PA documents:

1. The chronic IHI scenarios will not occur at the Area 5 or Area 3 facilities based on combined land-use restrictions of the NTS by the NNSA/NSO and the location of the facilities within areas that will prohibit groundwater access as specified in FFACO agreements.

2. The acute IHI scenarios are assumed to occur at the Area 3 and Area 5 facilities and the calculated doses for these scenarios will be included in the performance assessments.

3. The PA/CA will use a probability distribution for establishing when the MOP scenarios and acute IHI scenarios will occur and will use the resident without agriculture as the compliance scenario. The MOP will be assumed to be located at the UGTA-determined compliance boundary.

4. The well-drilling scenario is assumed to occur after loss of active institutional control at 100 years for consistency with the regulatory requirements of Title 40 CFR 191. 


\section{References}

Bechtel Nevada, 2006. A Hydrostratigraphic Model and Alternatives for the Groundwater Flow Bechtel Nevada, 2006. A Hydrostratigraphic Model and Alternatives for the Groundwater Flow and Contaminant Transport Model of Corrective Action Unit 97: Yucca Flat-Climax Mine, Lincoln and Nye Counties, Nevada. DOE/NV/11718--1119. Las Vegas, Nevada. January 2006.

, 2005. A Hydrostratigraphic Framework Model and Alternatives for the Groundwater Flow and Contaminant Transport Model of Corrective Action Unit 98: Frenchman Flat, Clark, Lincoln, and Nye Counties, Nevada. DOE/NV/11718--1064. Las Vegas, Nevada. September 2005.

2002. Addendum 1, Performance Assessment for the Area 5 Radioactive Waste Management Site at the Nevada Test Site, Nye County, Nevada; Reevaluation of the Chronic Inadvertent Human Intrusion Scenarios to Resolve the Disposal Authorization Statement Issues. DOE/NV/11718--176-ADD1. Las Vegas, Nevada. November 2001.

, 2001. Composite Analysis for the Area 5 Radioactive Waste Management Site at the Nevada Test Site, Nye County, Nevada. DOE/NV--594. Las Vegas, Nevada. September 2001.

Bechtel Nevada, and Neptune and Company, Inc., 2006. Addendum 2 to the Performance Assessment for the Area 5 Radioactive Waste Management Site at the Nevada Test Site, Nye County, Nevada. DOE/NV/11718--176-ADD2. Las Vegas, Nevada. June 2006.

Belcher, W. R. ed., 2004. Death Valley Regional Ground-Water Flow System, Nevada and California-Hydrogeologic Framework And Transient Ground-Water Flow Model. U.S. Geological Survey Scientific Investigations Report 2004-5205. Las Vegas, Nevada. June 2004.

Black, P., K. Black, L. Stahl, M. Hotten, T. Stockton, and D. Neptune, 2001. Assessing the Probability of Inadvertent Human Intrusion at the Nevada Test Site Radioactive Waste Management Sites. DOE/NV--593, Vols. I and II. Las Vegas, Nevada. March 2001.

BN, See Bechtel Nevada.

BN and Neptune, See Bechtel Nevada and Neptune and Company, Inc.

CFR, See Code of Federal Regulations.

Cochran, J. R., W. E. Beyeler, D. A. Brosseau, L. H. Brush, T. J. Brown, B. Crowe, S. H. Conrad, P. A. Davis, T. Ehrhorn, T. Feeney, B. Fogleman, D. P. Gallegos, R. Haaker, E. Kalinina, L. L. Price, D. P. Thomas, and S. Wirth, 2001. Compliance Assessment 
Document for the Transuranic Wastes in the Greater Confinement Disposal Boreholes at the Nevada Test Site. Vol. 2. Performance Assessment Version 1.1. SAND2001-2977. Sandia National Laboratories, Albuquerque, NM. September 2001.

Code of Federal Regulations. Title 40, Part 191, “ Environmental Radiation Protection Standards for Management and Disposal of Spent Nuclear Fuel, High-Level, and Transuranic Radioactive Wastes.” 2004.

Cowan, S. P., 1996. Memorandum to L. Dever, U.S. Department of Energy, Nevada Operations Office. Subject: "Conditional Acceptance of the Area 5 Performance Assessment." August 1996.

D’Agnese, F. A., C. C. Faunt, A. K. Turner, and M. C. Hill, 1997. Hydrogeologic Evaluation and Numerical Simulation of the Death Valley Regional Ground-Water Flow System, Nevada and California. U.S. Geological Survey Water-Resources Investigations Report 96-4300. Denver, Colorado.

DOE, See U.S. Department of Energy.

Federal Facility Agreement and Consent Order, 1996 (as amended) . Agreed to by the State of Nevada, U.S. Department of Energy, and U.S. Department of Defense, 1996. Federal Facility Agreement and Consent Order. May 10, 1996. Available at: http://empcs.nv.doe.gov/emis2/fa/pg/FFACO.pdf.[Accessed [Accessed April 12, 2007]

FFACO, see Federal Facility Agreement and Consent Order.

Fiore, J. J., 2001. Memorandum to K. A. Carlson, U.S. Department of Energy, National Nuclear Security Administration Nevada Site Office. Subject: "DAS for the Area 3 RWMS Revised Performance Assessment and Composite Analysis.” July 2001.

Fiore, J. J., 2000. Memorandum to K. A. Carlson, U.S. Department of Energy, National Nuclear Security Administration Nevada Site Office. Subject: "Disposal Authorization Statement for the Department of Energy Nevada Operations Office Nevada Test Site Area 5 Radioactive Waste Management Site Low-Level and Mixed Low-Level Radioactive Waste Disposal Facility.” December 2000.

Fiore, J. J., and M. W. Frei, 1999. Memorandum to K. A. Carlson, U.S. Department of Energy, National Nuclear Security Administration Nevada Site Office. Subject: "Conditional Acceptance of the Area 3 Performance Assessment and Composite Analysis." October 1999.

Frei, M. W., 2002. Memorandum to K. A. Carlson, U.S. Department of Energy, National Nuclear Security Administration Nevada Site Office. Subject: "Disposal Authorization for the Nevada Test Site Area 3 Radioactive Waste Management Site Submittal of Revised Performance Assessment and Composite Analysis dated December 17, 2001.” August 2002. 
Hewitt, W. M., K. L. Yuracko, and J. T. Greeves, 2006. “Inadvertent Human Intrusion into Closed Tank Farms at the Hanford Site.” RPP-2833, Rev 0. CH2MHill Hanford Group, Inc., Richland, WA. March 2006.

IT, see IT Corporation.

IT Corporation, 1999. External Peer Review Group Report on Frenchman Flat Data Analysis and Modeling Task, Underground Test Area Project. ITV/13052-0787. Las Vegas, Nevada. September 1999.

National Academies of Sciences, 1999. "Comments on the Proposed Radiation Protection Standards for Yucca Mountain, Nevada.” National Academies Press, Washington, D.C.

— 1995. “Technical Bases for the Yucca Mountain Standards.” National Academies Press, Washington, D.C.

National Security Technologies, LLC, 2007. Maintenance Plan for Performance Assessments and Composite Analyses of the Area 3 and Area 5 Radioactive Waste management Sites at the Nevada Test Site. DOE/NV/25946--091. Las Vegas, Nevada. January 2007.

NNSA/NSO see U.S. Department of Energy, National Nuclear Security Administration Nevada Site Office.

NSTec, see National Security Technologies, LLC.

Regnier, E.P., and A. Wallo, 2006. "Intergenerational Decision Making for Radioactive Waste Disposal, Policy and Science: Regulatory Protection Forever.” In: Proceedings, Waste Management'06, Tucson, Arizona. March 2006.

Shott, G. J., V. Yucel, M. J. Sully, L. E. Barker, S. E. Rawlinson, and B. A. Moore, 2000. Performance Assessment for the Area 3 Radioactive Waste Management Site at the Nevada Test Site, Nye County, Nevada (Rev. 2.1). Bechtel Nevada. DOE/NV--176-REV 2.1. Las Vegas, Nevada. October 2000.

Shott, G. J., L. E. Barker, S. E Rawlinson, M. J. Sully, and B.A. Moore, 1998. Performance Assessment for the Area 5 Radioactive Waste Management Site at the Nevada Test Site, Nye County, Nevada (Rev. 2.1). Bechtel Nevada. DOE/NV/11718--176. Las Vegas, Nevada. January 1998.

Stoller-Navarro, 2006. Phase II Groundwater Flow Model of Corrective Action Unit 98: Frenchman Flat, Nevada Test Site, Nye County, Nevada. S-N/99205--074. Las Vegas, Nevada. May 2006.

U.S. Department of Energy, National Nuclear Security Administration Nevada Site Office, 2006. "Project Screening and Siting Approval Process." Section III-2 b, "Restricted Use Zone.” Las Vegas, Nevada. May 2006 
U.S. Department of Energy, 2006. U.S Department of Energy Nevada Test Site Environmental Management End State Vision. DOE/NV--958. Las Vegas, Nevada. January 2006.

_ 2003a. DOE Policy P 455.1., “Use of Risk-Based End States.” Washington, D. C. May 2003.

— 2003b. DOE Policy P 455.1. “Use of Institutional Controls.” Washington, D.C. April 2003.

- 2002. Performance Management Plan. National Nuclear Security Administration, Nevada Site Office. Las Vegas, Nevada. August 2002.

_ , 2001a. DOE Order O 435.1, "Radioactive Waste Management.” U.S. Department of Energy, Washington, DC. July 9, 1999. Change 1, August 28, 2001

—, 2001b. DOE Manual M 435.1-1, “Radioactive Waste Management Manual.” U.S. Department of Energy, Washington, DC. July 9, 1999. Change 1, June 19, 2001.

_-1997. Regional Groundwater Flow and Tritium Transport Modeling and Risk Assessment of the Underground Test Area, Nevada Test Site, Nevada. DOE/NV--477, UC-700. Las Vegas, Nevada. October 1996. 